\title{
BACTERIA AND PROTOZOA POPULATIONS IN GROUNDWATER IN A LANDFILL AREA IN SÃO CARLOS, SP
}

\author{
Roberta Fusconi; Mirna Januária Leal Godinho* \\ Departamento de Ecologia e Biologia Evolutiva, Universidade Federal de São Carlos-UFSCar, \\ São Carlos, SP, Brasil
}

Submitted: December 12, 1997; Returned to authors for correction: September 17, 1998; Approved: April 06, 1999

\begin{abstract}
The microbial populations of groundwaters were analyzed in a region under the influence of a landfill (piezometer L12) in the town of São Carlos, São Paulo, Brazil, and in an area not influenced by the landfill (piezometer L5). Heterotrophic bacteria were counted by spread plate method and the number of protozoa was estimated by the most probable number method. There was a larger number of organisms in well L12, with a mean value of $15.76 \times 10^{4} \mathrm{CFU} / \mathrm{ml}$ for bacteria and $9.7 \mathrm{MPN} / \mathrm{ml}$ for protozoa, whereas the mean values for piezometer L5 were $2.88 \times 10^{4} \mathrm{CFU} / \mathrm{ml}$ for bacteria and 3.4 MPN/ml for protozoa. The greater abundance detected in piezometer L12 may be related to the influence of the leachate through the landfill on the microbial populations, also demonstrated by deoxygenation and by the high conductivity values $(3530 \mu \mathrm{S} /$ $\mathrm{cm})$ compared to piezometer L5 $(2.47 \mathrm{mg} / \mathrm{L}$ dissolved oxygen and $42 \mu \mathrm{S} / \mathrm{cm}$ conductivity). The most commonly detected protozoa were amoebae and flagellates. The density of flagellate protozoa determined under microaerophilic conditions was 10 times higher than that determined under aerobic conditions.
\end{abstract}

Key words: bacteria, protozoa, groundwater, landfill.

\section{INTRODUCTION}

Countries undergoing an accelerated process of industrialization face serious problems of pollution of underground waters that affect or will affect the drinking water supply for important segments of the population. Urban refuse, accumulated in large amount in cities, is often dumped on open surfaces or disposed of in landfills, with a potential risk of groundwater pollution $(8,19)$.

Because of the importance of groundwaters, it is essential to understand the behaviour of chemical and biological pollutants in the subsoil, the processes that govern this compartment and the interactions between microorganisms and abiotic factors. In this way it will be possible to prevent or relieve environmental and sanitary problems and to expand the knowledge needed for an integrated management of land systems, underground and surface waters.

The microbiology of groundwater is little known compared to that of surface waters and was studied on a small scale before 1970 (7). Bacterial populations predominate in the subsoil, accompanied by a smaller number of eukaryotic microorganisms such as the dormant forms of protozoa and fungi (13). Flagellates and amoebae are the major protozoa

\footnotetext{
* Corresponding author. Mailing address: Departamento de Ecologia e Biologia Evolutiva, UFSCar. Via Washington Luís, Km 235, Caixa Postal 676. CEP 13565-905, São Carlos, SP, Brasil. Fax: (+5516) 260-8322. E-mail: godinho@power.ufscar.br
} 
found in groundwaters $(20,25)$, although ciliated protists have also been detected in aquifers $(6,13)$. Protozoa are widely distributed in nature, are important components of aquatic ecosystems and are used as indicators of water quality. These characteristics show the potential of these organisms and the need of their ecologic study (22), with few reports, apparently only twenty publications (23), being available about protozoa in groudwaters.

In the present study we investigated the microorganisms populations and some abiotic variables in an area inside and outside the influence of a land fill within the boundaries of the towr of São Carlos in order to determine the possible effect of the leachate on the populations of bacteria and protozoa.

\section{MATERIALS AND METHODS}

Study area. The landfill is located in the rural region of São Carlos, in the upper part of the basin of the Ribeirão do Feijão stream, State of São Paulo, at $47^{\circ} 45^{\prime}-47^{\circ} 55^{\prime}$ longitude West and $22^{\circ} 00^{\prime}-22^{\circ} 15^{\prime}$ latitude South (24).

Sampling. Samples were collected monthly from May 1993 to April 1994 from two piezometers installed according to technical regulations (4). Piezometer L12 is $8.0 \mathrm{~m}$ deep and is under the action of the landfill, and piezometer L5 is $9.0 \mathrm{~m}$ deep and is located in an area outside the action of the landfill. After the water level was measured, the piezometer was depleted with a PVC tube ( 3 " in diameter and 2 $\mathrm{m}$ long) containing a valve at the lower end (3), in order to guarantee that stagnating water was replaced with freshly formed water. To avoid water contamination by external agents, a protective blanket was placed around the piezometer and the material used in the procedure of water depletion was disinfected with alcohol. The samples for physical and chemical analysis $(\mathrm{pH}$, water temperature, conductivity and dissolved oxygen Winker) and for microbiological control were collected with a bacteriologic sampler (3) containing glass flasks and sterile glass flasks, respectively. One sampler was used for piezometer L5 and another for piezometer L12.

Heterotrophic bacteria. The number of heterotrophic bacteria was estimated by inoculating plates containing $\mathrm{P}$ medium of the following composition: $1.0 \mathrm{~g} / \mathrm{L}$ peptone, $0.1 \mathrm{~g} / \mathrm{L}$ glucose, 0.1 $\mathrm{g} / \mathrm{L} \mathrm{K}_{2} \mathrm{HPO}_{4}, 0.02 \mathrm{~g} / \mathrm{L} \mathrm{FeSO}_{4}, 15.0 \mathrm{~g} / \mathrm{L}$ agar, $\mathrm{pH} 5.0$ (17). The material was incubated at $25^{\circ} \mathrm{C}$ for 15 days.

Protozoa. The density of protozoa was estimated by a modification of the technique described by Harris and Sommers (11). Six dilutions were used, with eight replication per dilution, for a total of 48 flasks $(10 \mathrm{ml})$ per well. A previously autoclaved unhulled kernel of rice was placed in each flask together with water from the well. The flasks were incubated at $25^{\circ} \mathrm{C}$ under conditions of aerobiosis and protected with a plastic bag in order to minimize evaporation. In April, the samples from piezometer L12 were also incubated under conditions of microaerophilia produced by a combination of iron, copper and sodium bicarbonate (15) and analyzed after 13 days of incubation. The material in the flasks was examined after 3, 6,9 and 12 days for piezometer L5 and after 4, 7, 10 and 13 days for piezometer L12. Microdrops $(10 \mu \mathrm{L})$ were analyzed for the presence or absence of protozoa and the results were quantified according to the table of Harris and Sommers (11).

\section{RESULTS}

The variation in density of heterotrophic bacteria during different periods of incubation was performed in order to determine the most adequate time of incubation. An increase in bacterial density was observed up to the 15 th day of incubation, with nonsignificant changes occurring thereafter.

Fig. 1 illustrates the bacterial counts in piezometer L5 and L12. In piezometer L12, under the influence of the landfill, the densities observed were of the order of $2.2 \times 10^{4}$ to $4.98 \times 10^{4} \mathrm{CFU} / \mathrm{ml}$ $\left(\mathrm{X}=2.88 \times 10^{4} \mathrm{CFU} / \mathrm{ml}\right)$. Fig. 2 shows the counts of protozoa for the two piezometers, with mean values of $9.7 \mathrm{MPN} / \mathrm{ml}$ for $\mathrm{L} 5$ and $3.4 \mathrm{MPN} / \mathrm{ml}$ for piezometer L12.

Fig. 3 compares the groups of protozoa detected during the study period. Amoebae were detected in both piezometers throughout the period of collection, while flagellates occurred only in March in piezometer L5 and throughout the collection period in piezometer L12. Piezometer L5 and L12 presented on average 1.50 and $4.47 \mathrm{MPN} / \mathrm{ml}$ amoebae and 0.96 and $1.47 \mathrm{MPN} / \mathrm{ml}$ flagellates, respectively. Ciliated microorganisms were observed on some occasions but could not be quantified by the method adopted. 


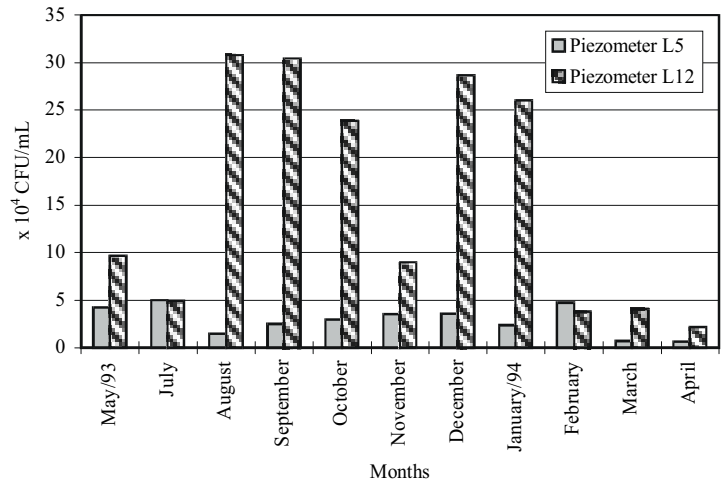

Figure 1. Counts of heterotrophic bacteria in groundwater (15 days of incubation at $25^{\circ} \mathrm{C}$ under conditions of aerobiosis). $\mathrm{CFU}=$ Colony forming units in $\mathrm{P}$ medium
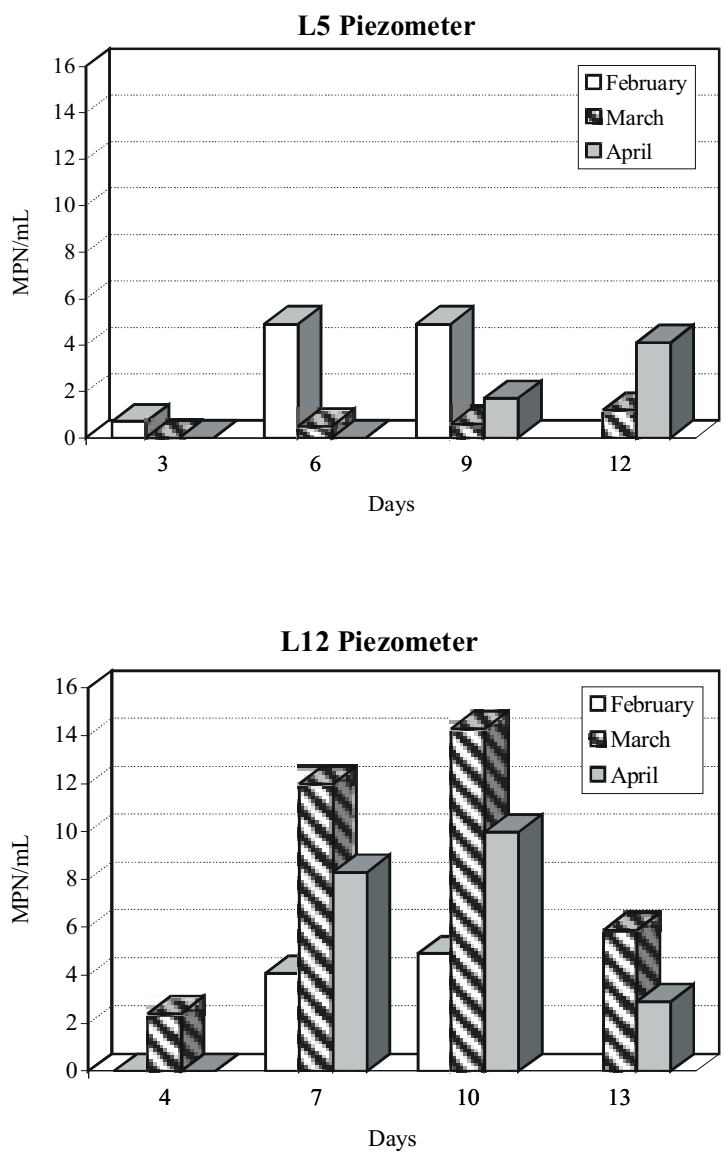

Figure 2. Counts of protozoa in groundwater. Incubation at $25^{\circ} \mathrm{C}$ under conditions of aerobiosis.
Fig. 4 compares the counts of protozoa in piezometer L12 after incubation under conditions of aerobiosis and microaerophilia. While the density of amoebae was similar for the two conditions, the density of flagellates was 10 times higher under conditions of microaerophilia than under conditions of aerobiosis. Different types of protozoa and cysts were observed, but only Colpoda steinii and Bodo lens were identified.

Table 1 shows air temperature and precipitation data and a comparison of the physical and chemical variables analyzed during the study period for piezometers L5 and L12. Air temperature ranged from $16.9^{\circ} \mathrm{C}$ to $24.5^{\circ} \mathrm{C}$ and accumulated monthly rainfall ranged from 6.2 to $282.0 \mathrm{~mm}$. Piezometer L5 presented a mean water temperature of $23^{\circ} \mathrm{C}$, acid $\mathrm{pH}$ (3.74), 32.2\% saturation with dissolved oxygen, conductivity of $42 \mu \mathrm{S} / \mathrm{cm}$ and a variation of the water column of 82.0 to $140.0 \mathrm{~cm}$. Piezometer L12 presented a mean water temperature of $25.1^{\circ} \mathrm{C}, \mathrm{pH}$ $6.7,0.3 \%$ saturation with dissolved oxygen, conductivity of $3530 \mu \mathrm{S} / \mathrm{cm}$, and variation of the water column from 71.0 to $123.0 \mathrm{~cm}$.

\section{DISCUSSION}

The organic compounds essential for the survival of heterotrophic bacteria in groundwater mainly originate from secondary organic compounds that percolate from the surface, and their quantity and quality depend directly on the reloading rate of the water table (7) and on the leaching of soil organic matter (2).

The greater abundance of organisms in piezometer L12 may be related to the influence of the leachate of the landfill on the populations since this material contains nutrients of fundamental importance for bacterial growth. An increase in biomass and in bacterial activity observed in oligotrophic groundwaters was attributed to the proximity to a source of pollution, suggesting the influence of organic contaminants (12). In a study of the leachate of the landfill in question, Gomes (9) showed that the material contained $203 \mathrm{mg} / \mathrm{L}$ ammonium nitrogen, $147 \mathrm{mg} / \mathrm{L}$ organic nitrogen and $3.8 \mathrm{mg} / \mathrm{L}$ total phosphorus. A study previously conducted by Gonçalves et al. (10) at the same site indicated the possible occurrence of infiltration of leaching material into the deep water table due to the direction of the phreatic flow associated with the high permeability of the local substrate. This 

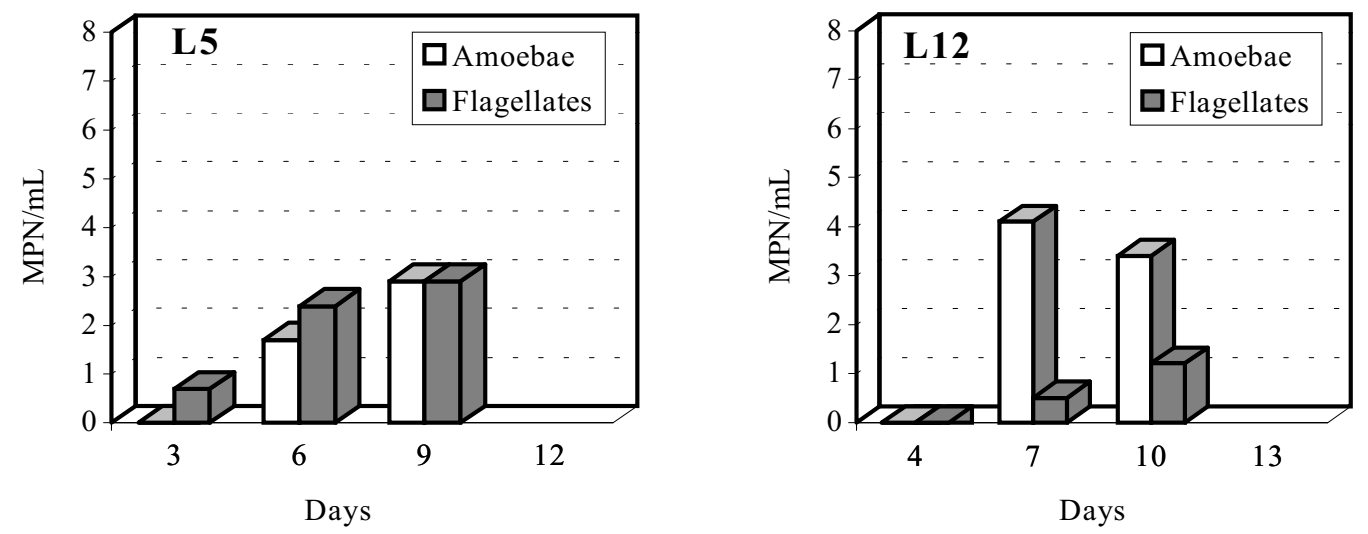

\section{MARCH}
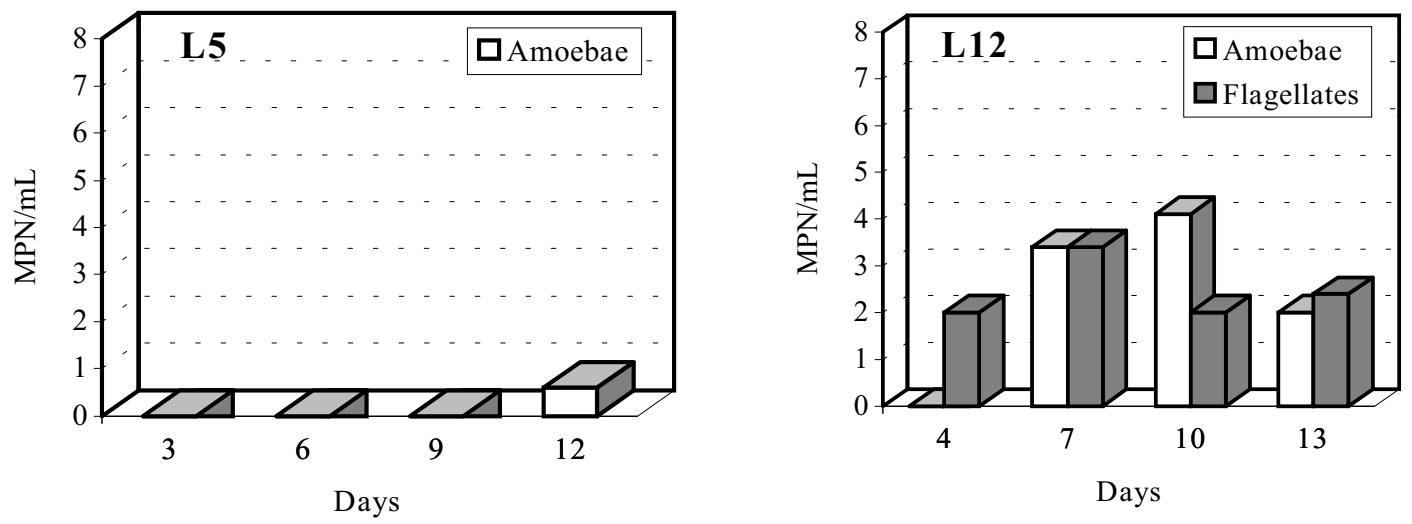

\section{APRIL}
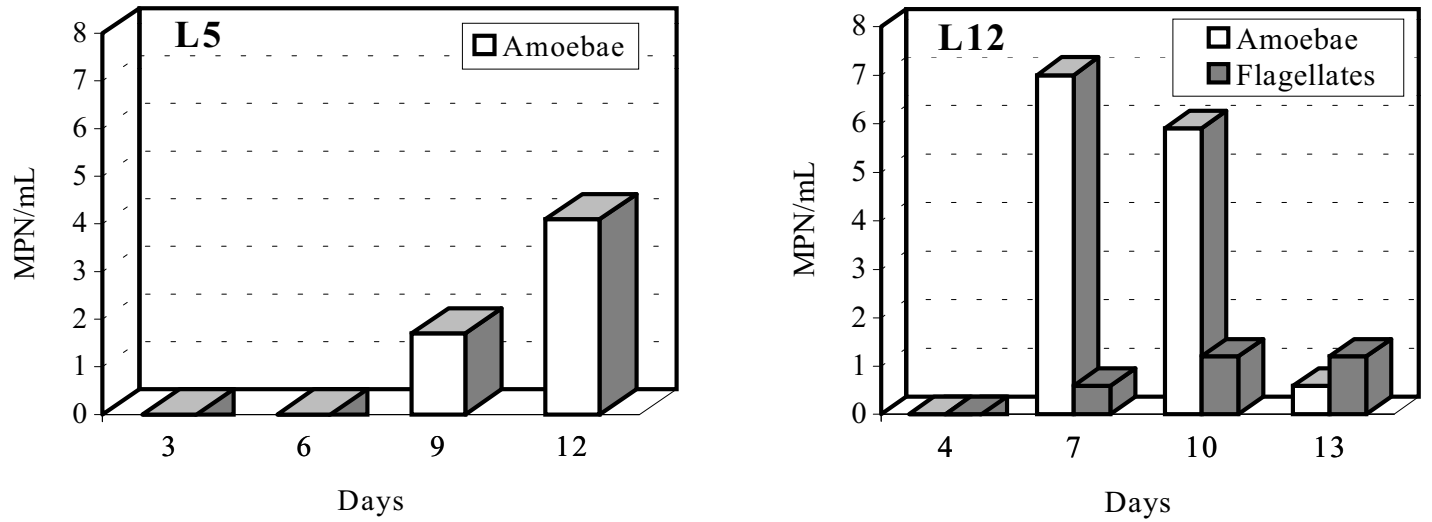

Figure 3. Counts of amoebae and flagellates in groundwater during the study period. Incubation at $25^{\circ} \mathrm{C}$ under conditions of aerobiosis. 


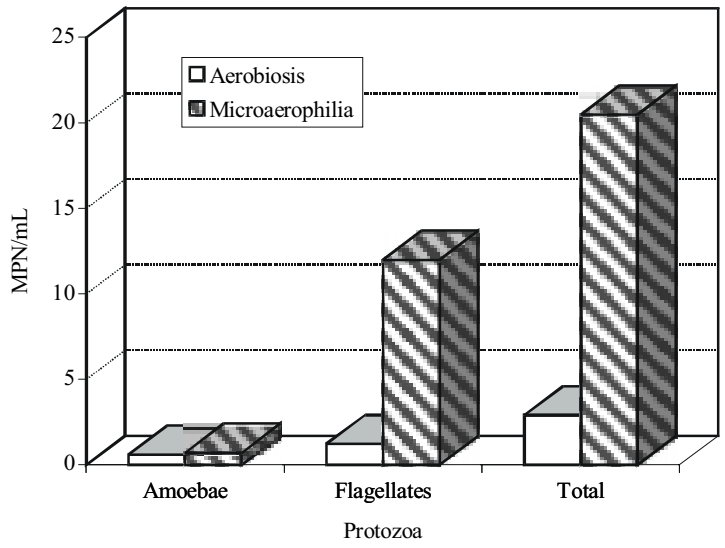

Figure 4. Counts of protozoa in piezometer L12 on the $13^{\text {th }}$ day of incubation at $25^{\circ} \mathrm{C}$ under conditions of aerobiosis and microaerophilia in April 1994.

possibility is emphasized by the high indices of bacteriologic indicators of fecal pollution in underground water in the area in question (3).

The results obtained for piezometer L5 are of the same order of magnitude as those observed by Harvey et al. (12), who detected $4.1 \pm 0.3 \times 10^{4}$ bacteria/ml and $4.2 \pm 0.5 \times 10^{4}$ bacteria/ml in two noncontaminated water tables, respectively. The small number of organisms detected in piezometer L5 compared to piezometer L12 may be related to the nutritional scarcity of the environment. This fact may limit microbial abundance in water tables, especially with respect to sources of organic carbon, nitrogen and phosphorus, with no limitation occurring for sulphur and other minerals (7). The influence of the leachate on piezometer L12 was also observed on the basis of conductivity, which was on the average 84 times higher than in piezometer L5, and on the basis of the concentration of dissolved oxygen, which was not detected in the samples, with the exception of one sampling date.

By comparing the present data with those obtained by Bossolan (3) in a study carried out at the same site and using the same culture medium, the bacterial density observed in piezometer L12 was twice higher and the density observed in piezometer L5 was 1.5 times lower.

The development of bacterial colonies in $\mathrm{P}$ medium, which is nutritionally poor, was slow and the largest number of colonies was obtained after 15 days of incubation. Jannasch and Jones (14) stated that, since many colonies only become visible after $72 \mathrm{~h}$ of incubation, the culture of bacteria in more diluted media should last more than one week, thus guaranteeing the formation of a larger number of colonies.

The higher density of protozoa in piezometer L12 supports the statement made by Sinclair et al. (25)

Table 1 - Chemical and physical variables in L5 and L12 piezometers.

\begin{tabular}{|c|c|c|c|c|c|c|c|c|c|c|c|c|c|c|}
\hline \multirow[b]{2}{*}{$\begin{array}{l}\text { Month/ } \\
\text { Piezometer }\end{array}$} & \multirow[t]{2}{*}{$\begin{array}{l}\text { Precipitation } \\
\quad \text { (mm) }\end{array}$} & \multirow[t]{2}{*}{$\begin{array}{l}\text { Air } \\
\left({ }^{\circ} \mathrm{C}\right)\end{array}$} & \multicolumn{2}{|c|}{$\begin{array}{l}\text { Water } \\
\left({ }^{\circ} \mathrm{C}\right)\end{array}$} & \multicolumn{2}{|c|}{$\begin{array}{l}\text { Water column } \\
\text { (cm) }\end{array}$} & \multicolumn{2}{|c|}{$\mathrm{pH}$} & \multicolumn{2}{|c|}{$\begin{array}{c}\text { Dissolved } \\
\text { oxygen } \\
(\mathrm{mg} / \mathrm{L})\end{array}$} & \multicolumn{2}{|c|}{$\begin{array}{c}\text { Oxygen } \\
\text { saturation } \\
(\%)\end{array}$} & \multicolumn{2}{|c|}{$\begin{array}{c}\text { Conductivity } \\
(\mu \mathrm{S} / \mathrm{cm})\end{array}$} \\
\hline & & & L5 & $\overline{L 12}$ & L5 & L12 & L5 & L12 & L5 & L12 & $\mathbf{L 5}$ & L12 & L5 & L12 \\
\hline May/93 & 59.1 & 20.2 & 23.0 & 25.5 & 128.0 & 113.0 & 3.95 & 6.81 & 2.74 & 0 & 35.6 & 0 & 35.0 & 2700.0 \\
\hline July & 62.1 & 16.9 & 22.0 & 24.0 & 140.0 & 112.0 & 3.66 & 6.64 & 2.37 & 0.26 & 30.3 & 3.44 & 44.0 & 3300.0 \\
\hline August & 6.2 & 17.3 & 23.0 & 25.0 & 121.0 & 98.0 & 3.64 & 6.53 & 1.7 & 0 & 22.1 & 0 & 42.0 & 3700.0 \\
\hline September & 43.6 & 17.6 & 22.0 & 23.5 & 109.0 & 96.5 & 3.54 & 6.55 & - & 0 & - & 0 & 44.0 & 3900.0 \\
\hline October & 140.8 & 20.0 & 24.0 & 26.0 & 104.0 & 92.0 & 3.28 & 6.53 & 1.97 & 0 & 26.1 & 0 & 46.0 & 3400.0 \\
\hline November & 111.6 & 22.2 & 23.5 & 25.0 & 94.0 & 80.0 & 3.33 & 6.55 & 4.46 & 0 & 58.4 & 0 & 45.0 & 3600.0 \\
\hline December & 128.9 & 24.0 & 23.0 & 25.0 & 85.0 & 75.5 & 4.21 & 6.69 & 2.23 & 0 & 33.0 & 0 & 40.0 & 3700.0 \\
\hline January/94 & 198.7 & 19.8 & 21.5 & 24.5 & 82.0 & 74.0 & 4.31 & 6.81 & 1.94 & 0 & 24.6 & 0 & 36.0 & 3500.0 \\
\hline February & 282.0 & 24.5 & 25.0 & 27.0 & 97.0 & 80.0 & 3.27 & 6.78 & 2.87 & 0 & 38.6 & 0 & 40.0 & 3700.0 \\
\hline March & 89.3 & 22.8 & 23.0 & 25.5 & 106.0 & 123.0 & 4.33 & 6.85 & 2.71 & 0 & 35.3 & 0 & 47.0 & 3700.0 \\
\hline April & 89.6 & 21.7 & 23.0 & 25.0 & 92.50 & 71.0 & 3.62 & 6.92 & 1.37 & 0 & 17.8 & 0 & 44.0 & 3600.0 \\
\hline Average & 110.17 & 20.64 & 23.0 & 25.1 & 105.0 & 92.3 & 3.74 & 6.7 & 2.47 & 0.02 & 32.1 & 0.30 & 42.0 & 3530.0 \\
\hline
\end{tabular}

- No data 
about the probable greater abundance of protozoa at sites with organic contamination of the subsoil, with possible important ecologic roles for these organisms in these environments.

It is possible that the protozoa counted by the method employed were underestimated. Since this is an estimate based on the presence and absence of protozoa, even though the organisms were detected in 1, 2 or 3 flasks, the density would have been zero on the basis of the table used. An underestimate of the number of protozoa in the sediment may occur with the use of this method since not all organisms develop in enriched cultures due to culture conditions or feeding incompatibility (25). Another problem detected during the enumeration of protozoa was the occurrence of temporary encysting for nuclear reorganization and multiplication (18), which may occur for Colpoda steinii, or the possible occurrence of a resistance cyst in unfavourable environmental situations (21). This fact may have led to an underestimate of ciliated organisms, since, depending on the time when counts were performed, some organisms may have been encysted.

It is difficult to determine precisely whether or not a microorganism is native to the subsurface environment. The protozoa detected may reach the water table through hydrologic flow and may become encysted when they do not find conditions favourable to development.

Incubation of samples from piezometer L12 under microaerophilic conditions showed that the protozoa may be metabolically active under anaerobic and/or microaerophilic conditions, and that they may become encysted under aerobic conditions.

In conclusion, the microorganisms observed were mainly flagellates and amoebae while ciliates were observed in much lower numbers. Colpoda steinii was observed both encysted and as trophic cells in different periods of the same day. This observation shows that care is needed to avoid estimation errors as well as the urgency of studies related to encysted versus trophic cells (23).

The high numbers of bacteria and protozoa detected in the contaminated piezometer may play a key role in the self-purification processes of the aquifer. The bacteria may be using different organic pollutants as substrate and protozoa, witch are the main consumers of bacteria in nature, may control the bacteria populations (16), stimulate the bacterial activity and reduce the number of pathogens (5) present in the system. On the other hand, careful considerations should be given to the fact that protozoa may harbour pathogenic bacteria. It has been shown that Legionella pneumophila has the ability to survive and replicate within protozoa, improving its resistance to physical and biochemical agents used in bacterial eradication and therefore may contribute to the increase of bacteria in the environment (1).

\section{ACKNOWLEDGEMENTS}

We are grateful to FAPESP (Fundação de Amparo a Pesquisa do Estado de São Paulo) for a Scientific Initiation Fellowship and to CRHEA-EESC-USP for providing climatologic data.

\section{RESUMO}

\section{Populações de bactérias e protozoários em águas subterrâneas na área de um aterro controlado em São Carlos, SP}

Foi feita a análise das populações microbianas na água subterrânea da região sob a influência do aterro controlado da cidade de São Carlos, São Paulo, Brasil (poço L12) e sem a influência do mesmo (poço L5). As bactérias heterotróficas foram enumeradas pelo método de espalhamento em placa e o número de protozoários foi estimado pelo método do número mais provável. Observou-se um maior número de organismos no poço L12, com uma média de bactérias de $15,76 \times 10^{4} \mathrm{UFC} / \mathrm{ml}$ e $9,7 \mathrm{NMP} / \mathrm{ml}$ de protozoários. No poço L5 foi detectada uma média de bactérias de $2,88 \times 10^{4}$ $\mathrm{UFC} / \mathrm{ml}$ e $3,4 \mathrm{NMP} / \mathrm{ml}$ de protozoários. A maior abundância encontrada no poço L12 pode estar relacionada à influência do chorume do aterro controlado sobre as populações microbianas, evidenciada também pela desoxigenação e pelos altos valores de condutividade $(3530 \mu \mathrm{S} / \mathrm{cm})$ quando comparados ao poço L5 $(2,47 \mathrm{mg} / \mathrm{L}$ de oxigênio dissolvido e $42 \mu \mathrm{S} / \mathrm{cm}$ de condutividade). Os protozoários mais comumente observados foram as amebas e os flagelados. A incubação de protozoários flagelados em condições microaerofílicas foi mais favorável, dando uma densidade 10 vezes maior do que em aerobiose.

Palavras-chave: bactérias, protozoários, água subterrânea, aterro controlado. 


\section{REFERENCES}

1. Abu Kwaik, Y.; Gao, L.-Y.; Stone, B.J.; Venkataraman, C. Harb, O.S. Inavsion of protozoa by Legionella pneumophila and its role in bacterial ecology and pathogenesis. Appl. Environ. Microbiol., 64: 3127-3133, 1998.

2. Beloin, R.M.; Sinclair, J.L.; Ghiorse, W.C. Distribution and activity of microorganisms in subsurface sediments of a pristine study site in Oklahoma. Microb. Ecol., 16: 85-97, 1988.

3. Bossolan, N.R.S. Aspectos ecológicos das populações bacterianas em águas subterrâneas sob o efeito de um aterro controlado. São Carlos, 1993, 120p. (M.Sc. Departamento de Ecologia e Biologia Evolutiva. UFSCar).

4. CETESB. Construção de Poços de Monitoramento de Aqüifero Freático. CETESB 06.010. São Paulo, 1988.

5. Curds, C.R. Protozoa in the Water Industry. Cambridge University Press, Cambridge, 1992, 122p.

6. Foissner, W. Ciliates in rapid gravity filters of water-works exploiting deep groundwaters. Microsc. Res. Tech. 33: 1222, 1996.

7. Ghiorse, W.C.; Wilson, J.T. Microbial ecology of the terrestrial subsurface. Adv. Appl. Microbiol., 33: 107-172, 1988.

8. Gibert, J.; Danielopol, D.L.; Stanford, J. Groundwater Ecology. Academic, San Diego, 1994, 571p.

9. Gomes, L.P. Avaliação da atividade bacteriana anaeróbia celulitica do chorume originado em sistemas de disposição de resíduos sólidos urbanos a céu aberto. São Carlos, 1995, 210p. (Ph.D. Thesis. Departamento de Hidráuluca e Saneamento, USP-EESC).

10. Gonçalves, A.R.L., Bossolan, N.R.S.; Godinho-Orlandi, M.J.L. Determinação da direção do fluxo freático no aterro sanitário de São Carlos. $7^{\circ}$ Congresso Brasileiro de Águas Subterrâneas, Belo Horizonte, 1992, 114-118.

11. Harris, R.F.; Sommers, L.E. Plate-dilution frequency technique for assay of microbial ecology. Appl. Microbiol. 16: 330-334, 1968.

12. Harvey, R.W.; Smith, R.L.; George, L. Effect of organic contamination upon microbial distributions and heterotrophic uptake in a Cape Cod, Mass., Aquifer. Appl. Environ. Microbiol. 4: 1197-1202, 1984.
13. Hirsch, P.; Rades-Rohkohl, E. Microbial diversity in a groundwater aquifer in northern Germany. Develop. Ind. Microb. 24: 183 - 200, 1983.

14. Jannasch, H.W.; Jones, G.E. Bacterial populations in seawater by different methods of enumeration. Limnol. Oceanogr. 4 128-139, 1959.

15. Jurgensen, C.A. Caracterização preliminar, a nível de gênero, para bactérias anaeróbias predominantes em material clínico. Rev. Pat. Clin. 17: 74-77, 1981.

16. Kinner, N.E.; Harvey, R.W.; Kazmierkiewicz-Tabaka, M Effect of flagellates on free-living bacterial abundance in an organically contaminated aquifer. FEMS Microb. Rev., 20: 249-259, 1997.

17. Kölbel-Boelke, J.; Tienken, B.; Nehrkorn, A. Microbial communities in the satured groundwater environment I: Methods of isolation and characterization of heterotrophic bacteria. Microb. Ecol. 16: 17-29, 1988.

18. Kudo, R.R. Protozoology. Charles C. Thomas, Illinois, 1971, $1174 \mathrm{p}$.

19. Lima, L.M.Q. Lixo: Tratamento e Biorremediação. Hemus, São Paulo, 1995, 265p.

20. Madsen, E.L.; Ghiorse, W.C. Groundwater microbiology: subsurface ecosystem processes. In: Ford, T.E. (eds.). Aquatic Microbiology. Blackwell, Boston, 1993, p.167-214.

21. Martin-Gonzales, A.; Benitez, L.; Gutierrez, J.C. Cortical and nuclear events during cell division and resting cyst formation in Colpoda inflata. J. Protozool., 38: 338-344, 1991.

22. Moravtseva, V. Protozoa as assay and indicator organisms for monitoring water quality. Hydrobiol. J., 24: 29-33, 1988.

23. Novarino, G.; Warren, A.; Butler, H.; Lambourne, G.; Boxshall, A.; Bateman, J.; Kinner, N.E.; Harvey, R.W.; Mosse, R.A.; Teltsch, B. Protistan communities in aquifers: a review. FEMS Mirob. Rev. 20: 261-275, 1997.

24. Prado, H.; Oliveira, J.B.; Almeida, C.L.F. Levantamento pedológico semi detalhado do Estado de São Paulo: quadrícula de São Carlos. Instituto Agronômico, Campinas, 1981.

25 Sinclair, J.L.; Kampbell, D.K.; Cook, M.L.; Wilson, J.T. Protozoa in subsurface sediments from sites contaminated with aviation gasoline or jet fuel. Appl. Environ. Microbiol. 59: 467 - 472, 1993. 